\title{
The Mediation Role Of Brand Preference On The Relationship Between Consumer-Based Brand Equity And Word Of Mouth Marketing
}

\author{
Erkan Yıldız \\ Başkent University \\ Kazan Vocational School \\ Kazan, Ankara, Turkey \\ eryildiz967@gmail.com
}

\author{
Ayşe AKYOL \\ Trakya University \\ Faculty of Economics and Administrative \\ Sciences, Edirne, Turkey \\ ayseakyol@trakya.edu.tr
}

\begin{abstract}
The most important asset needed to achieve the competitive advantage is having a strong brand equity. In this study, the relations between the dimensions of consumerbased brand equity and those of word of mouth marketing were analysed. In addition, the mediating role of the brand preference was checked. The sample consisted of 1000 people living in Istanbul, Ankara, and Izmir. The sampling method used was quota sampling. In the conclusions of this study, it was observed that: there are effects of brand awareness and brand association dimensions on the negative word of mouth marketing, perceived quality on the positive and negative word of mouth marketing, and brand loyalty on the positive word of mouth marketing. Brand preference has a partial mediation role in the relations between the perceived quality dimension of consumerbased brand equity and the dimensions of positive and negative word of mouth marketing.
\end{abstract}

Keywords: Consumer-Based Brand Equity, Word of Mouth Marketing, Brand Preference.

\section{Introduction}

According to the studies, $70 \%$ of the market values of the enterprises are comprised of abstract assets. The most valuable of the assets like patents, licenses, know-how, and customer data base, is the brand equity. That is why the enterprises may sometimes be sold or bought for high prices due to their brand equities (Temporal, 2011, p. 21).

The most effective methods to stimulate the repetitive purchases, the change of brands, and the incline to definite brand preferences through the creation of high brand equity, are the Word of Mouth Marketing (WOM). In the studies conducted on the effects of WOM on the consumers, it was observed that it is seven times more efficient than the newspapers and magazines, four times more efficient than the individual sales, and two times more efficient than the radio advertisements (Sarış1k and Özbay, 2012, 
p. 6). WOM has also other superiorities such as easiness and cheapness as compared to the other assets as well. According to Kotler (2011, p. 84), WOM had a considerable effect on the success of some global enterprises like Starbucks and Wal-Mart.

The concept was examined under the sub dimensions of; consumer-based brand equity, brand awareness, brand association, perceived quality, and brand loyalty, along with the positive and negative sub dimensions of WOM. In addition, some assertions were provided on the mediation role of the brand preference in the relationship between brand equity and WOM.

It is assessed that the findings of this study will contribute to the literature, while providing some insights to the high level managers, as well as the marketing and branding managers of the enterprises so as to assist in the development of their marketing strategies. It may be referred that the enterprises can establish an emotional tie with their customers through their brands and consequently increase the loyalty of their customers in a positive manner. It is further assessed that the increase in the loyalty of the customers will help their preservation against the attractive attempts of the rival enterprises to change their brand preferences while they possibly assume a volunteer representation role to encourage their environments in buying their brands by extending their own positive attitudes in all types of events and social media relations in which they are involved. It may further be referred that the enterprises will achieve this competitive advantage without suffering any additional cost and make benefit of the easiness and cheapness of WOM.

\section{Literature Review}

\subsection{The Concept of Brand}

A brand is the identity which creates competitive differences betweeen rivals and which appears sometimes in the shape of rational and solid commitments and sometimes in the appearance of abstract and symbolic messages (Keller, 2003). Brands usually have a logo, trademark, differentiating name, or symbol, which helps the companies to increase the prominence of their products as well as to differentiate them from those of the rivals' (Aaker, 2009) and it is also the communication between the producers and the customers (Tosun, 2014).

Brands inform the customer and establishes the familiarity of the product (Kotler et al., 1996, p. 551). A brand is the quality assurance of the customer mitigating the risks they perceive (Tosun, 2014). Brands provide assurance on the product specifications to the customers as well (Chiaravalle and Schenck, 2013, p. 10; Clifton, 2014, p. 26).

Brands help the promotion of the companies as they are also effective for demand creation. As such, a brand which is successful in the market renders its company to follow a pricing strategy different than the rivals (Kotler, 2012, p. 86). Brands provide a company the ability to diversify the products while it increases the ownership by which the company is differentiated by the rivals (Hatch and Schultz, 2012, p. 42). Brands enable permanency from the emotional tie it creates, which in turn enables the remembrance and which respectively provides the opportunities to preserve up to dateness (Kaputa, 2012, p. 35). 


\subsection{Brand Equity}

The concept of brand is far beyond being a tool to inform on the quality and the symbolic value of the product nowadays. Ries and Ries, by stating that the brand on the product is not the same brand in the customer's mind, draws the attentions to the fact that the concept of brand is dependent on the abstract perceptions which are far beyond the physical and imaginary specifications (2005, p. 13).

As such, the brands themselves are regarded among the financial assets of the enterprises while they may be subject to purchase and sale activities. The enterprises, having strong brands, attain the possibility to continue their life for long terms with their advantages of sustainable competitiveness. The strong brands similarly, can enable their companies to be known with much higher values than their actual financial values. To set an example, the brand equity of 127-year-old Coca - Cola which was started to be sold as a tonic in 1886 by a pharmacist from Atlanta reached 48 billion U.S. Dollars in 2000 (Kotler, 1999, p. 405), 70 billion U.S. Dollars in 2003 (Kotler, 2011, p. 83), and eventually 79.2 billion U.S. Dollars in 2013 (http://interbrand.com).

Brand equity can be defined as the value added by a brand to the product (Farquar, 1989), the reflection of the competitiveness of the brand inside the market (Kavas, 2004, p. 16), and the compilation of the good will and positive effects (Odabaş1 and Oyman, 2007, p. 372), as well the employment of an existing brand while entering into a new product segment (Erdil and Uzun, 2010).

The literature definitions of brand equity depends on two perspectives. Depending on a financial perspective, the corporation value becomes prominent, while in the second definition made from a marketing stand point, the consumer-based brand equity gains gravity (Pappu, Quester and Cooksey, 2005, p. 144).

\subsection{Consumer-Based Brand Equity}

Consumer-based brand equity is depicted as the equity attributed to the brand by the consumers (Aaker, 1991), a factor creating a positive effect in the preferences of the consumers for the brand (Park and Srinivasan, 1994), and the factors affecting the demand by the experience and knowledge of the consumers accumulated by that time (Keller, 1998).

Consumer-based brand equity is defined in different dimensions. However, the most widespread of them is the one made by Aaker (1991), which is applied in this study as well. These dimensions are respectively: brand awareness, brand association, perceived quality, and brand loyalty. These dimensions can be defined as followed.

\subsubsection{Brand Awareness}

Brand awareness is the place attributed to the brand by the consumers as a result of comparisons with the other brands and the strength of the brand with its existence in the consumers' mind. This may also be defined as the familiarity and remembrance of the brand by the consumers and their attribution to it a more prominent place in their minds (Aaker, 1991, 2009).

Brand awareness includes brand association and brand recognition. Brand association easily and differently depicts, identifies, and informs the consumers of the brand when seeing, hearing, and comparing it with the other brands. Brand recognition 
on the other hand, shows how the consumers can remember a brand when rendered a clue on the name and/or the usage condition of a product category (Pappu, Quester and Cooksey, 2005, p. 145).

\subsubsection{Brand Association}

Brand association is everything that attributes to the brand, established in the minds of the consumer (Aaker, 1991). It is the characteristic features that the consumers perceive (Keller, 1993) and is the connection that the consumers establish with the brand in their minds (Erdil and Uzun, 2010, p. 244).

McDonald's with its symbol of the Gold Belt, Marlboro with its symbol of the cowboy Marlboro Man character, Arçelik with its characterization on Iron, Mercedes and BMW with the luxury and prestige they provide, Porsche with success and money, and Volvo with endurance and reliability, have established such connotations in the minds of the consumers (Erdil and Uzun, 2010, p. 244). The most important feature of brand associations is them being related to consumers' sub consciousness. (Ayas, 2012)

\subsubsection{Perceived Quality}

Perceived quality is the permanency of the value established in the minds of the consumers (Keller, 1993). It may be referred to as the perfection points, the respectfulness and performance of a brand in the eyes of the consumer in comparison with those of the rival products (Netemeyer et al., 2004, p. 210), and as the consumer perception on the overall quality and supremacy of the products provided by the companies as compared with the other ones (Aaker, 2009, p. 106) and consumers' general evaluations about the products and services (Ural and Perk, 2012).

It is indeed very hard to determine the perceived quality objectively due to the perceptions of the consumers. The perception of one consumer may not overlap with that of another. A product regarded as qualified by one consumer, may not bear the same meaning for another consumer (Tosun, 2014). Therefore, one must not confuse the perceived quality with the satisfactory attitude of the consumers. A low level of performance may be acceptable for a consumer who expects a low performance from a product whereas it may not be possible to mention the same satisfaction vice versa. Similarly, while a product of a low quality may produce a positive attitude from the consumer due to its inexpensiveness, a high quality expensive product may not yield to the same positive outcome for the consumers (Aaker, 2009, pp. 106-107).

\subsubsection{Brand Loyalty}

Brand loyalty can be described as: the probability of a consumer going for another brand that changed the price and the features of their products in particular (Aaker, 2009 , p. 58); a decision-making unit in between a pool of brands in time and a noncoincidental behavioral response given to one or multiple alternative brands (Taşkın and Akat, 2010, p. 6). Kocaman and Güngör stated brand loyalty as the essence of brand equity (2012).

On the other hand, the brand loyalty should not be regarded the same as the repetitive purchase of a product by the consumer. Brand loyalty is the function of the compilation of the regular attitude, reactions, and physiological process, to be 
developed by the time among other brand groups while the purchases are realized in a conscious manner rather than being the result of coincidences (Tosun, 2014).

\subsection{Brand Preference}

Brand preference can be described as the preference of a brand in conclusion of evaluations made during the buying process under the effect of the consumers' needs and the consumers' attitude about the brand (Keskin and Y1ldiz, 2010).

There are several reasons for the consumers' preferences for a definite brand, varying from the consumer requirement specifications, the brand imagination, the consumer perceptions, the efficiency of the marketing activities, and to some social, physiological, personal, and environmental reasons (Keskin and Y1ldiz, 2010, p. 240).

\subsection{Word of Mouth Marketing (WOM)}

WOM can be described as unoffical sharing of experiences and information gained after the use of products and services between consumer groups (Yazgan, Kethüda and Çat1, 2014, p. 240). Sernovitz described WOM as presenting an idea worth talking on, making the consumers talk about the products and making the talk spread easier (2012, p. 29).

The information gathered through WOM is regarded to be more reliable in the eyes of the consumers since they are not collected from the mass media and sales persons. Moving from this reliability, the consumer realizes his/her purchase by considering the advices from family members or friends. This is also a quicker and shorter way of reaching the reliable information by WOM for the consumers, as they do not have enough time to consider and review the excessive number of messages they face due to a consequence of living in the information age (Karaca, 2010, p. 4).

\subsection{Relations Between Variables}

Cobb-Walgren, Ruble, and Donth (1995) conducted a research on household cleaning brands that have low risk perception and hotels that have high risk perception in order to research the effects of brand value on the brand preferences and purchase intent. The authors stated that the brand equity influenced the brand preference positively and the brands that have more advertising expenditure, have higher quality perception and brand awareness.

Meyers (2003) demonstrated the effects of the brand equity on brand preference in his research of about 9 most-known soft drink brands and with the participation of university students in the south western United States.

Chen and Chang (2008), in the study they performed with 480 passengers in the Taiwan international airport, researched the effects of brand equity on brand preference, purchase intent, and the regulatory role of the conversion cost in this relationship. At the end of the research, it has been demonstrated that the brand equity affects the brand preference in a positive direction.

Çiftci and Kocak (2009) studied the effects of brand loyalty, customer satisfaction, and inactive word of mouth communication on active word of mouth communication. The study was conducted on shampoo, which is a low featured product, and the mobile phone, which is a full-featured product. According to the results of the study, it was found that brand loyalty has positive effects on active word of mouth communication. 
Moradi and Zerai (2011) conducted a study about the effects of the brand equity on the brand preference, purchase intent, and about the moderating role of the country of origin in this relationship. They detected that the brand equity affects the brand preference positively in their studyof about 700 students from 3 different state universities in Iran who have laptops and cell phones.

Tolba (2011) has studied the effects of brand awareness, perceived quality, request, satisfaction, and intensity distribution on brand loyalty and brand preference. They studied to determine the moderating role of the country. At the end of the study, it has been found that perceived quality affects the brand preference positively and brand awareness affects the brand preference negatively.

Yazgan, Kethüda, and Çatı (2014) have examined the effects of consumer based brand equity components on each other and the effects of these dimensions on the WOM. According to the survey results, it has been expressed that while the brand loyalty and perceived quality dimensions affect the WOM directly, the dimensions of perceived quality, brand association, and brand awareness affect WOM indirectly.

The literature has not been faced with a study examining the effects of brand preference on WOM. Thus, it has been assessed that this study can contribute to the literature.

\section{Methodology}

This study reflects a practical research from the collected data of which is analyzed through the statistical programs of SPSS Statistics 21 and SPSS AMOS 21. The structural equation modeling is employed for the determination of the hypothesis and of the mediation effect. The research model and the hypothesis to be tested was determined upon the literature review listed below.
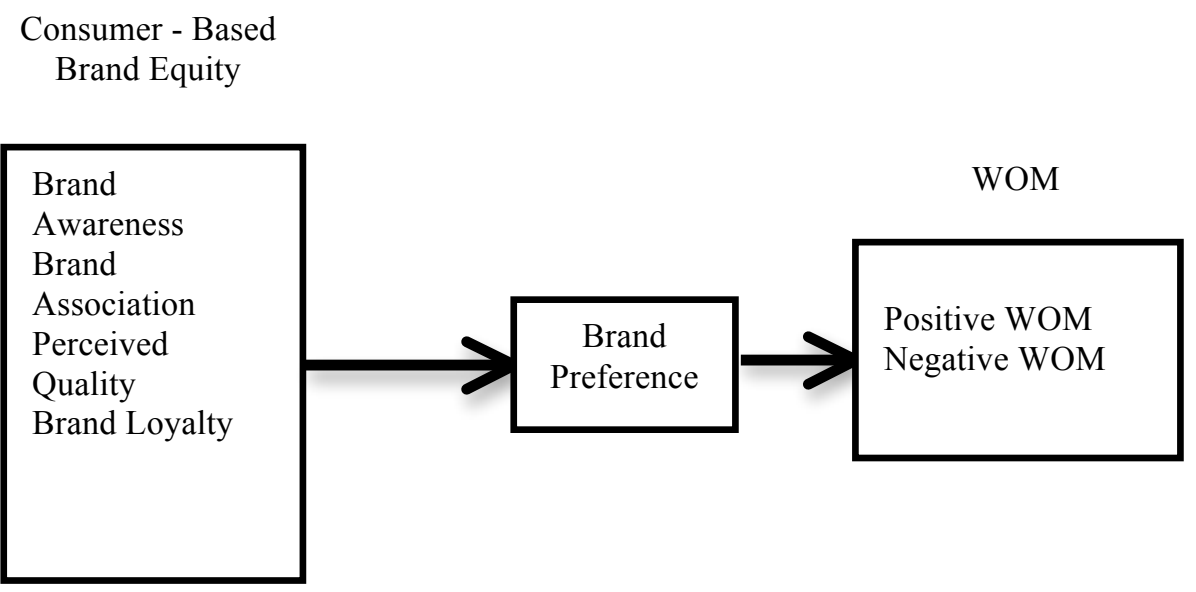

Figure 1 Research Model

$\mathbf{H}_{1}$ : There is a significant relationship between brand awareness and the positive WOM.

$\mathbf{H}_{2}$ : There is a significant relationship between brand awareness and the negative WOM.

$\mathbf{H}_{3}$ : There is a significant relationship between brand association and the positive WOM.

$\mathbf{H}_{4}$ : There is a significant relationship between brand association and the negative WOM.

$\mathbf{H}_{5}$ : There is a significant relationship between perceived quality and the positive WOM. 
$\mathbf{H}_{\mathbf{6}}$ : There is a significant relationship between perceived quality and the negative WOM.

$\mathbf{H}_{7}$ : There is a significant relationship between brand loyalty and the positive WOM.

$\mathbf{H}_{\mathbf{8}}$ : There is a significant relationship between brand loyalty and the negative WOM.

$\mathbf{H}_{9}$ : There is a mediating role of the brand preference between the relation of consumerbased brand equity and WOM.

\subsection{Participants}

The main population of this research is comprised of the computer owning people living in Istanbul, Ankara, and Izmir, which are the three big cities in Turkey.

The employment of sampling techniques which are not based on probability is regarded to be more appropriate especially in the marketing-related researches where the chance of availability of everybody existent in the population is not equal with the chance to exist in the sample (Altunış1k et al., 2012, p. 141). Because of this, it is regarded that the Quota Sampling technique, which is among the sampling types not depending on probability, is more appropriate for this study. The biggest cities of Turkey; Istanbul, Ankara, and Izmir are included in the application of the Quota technique and the quota ratios defined in accordance with the population of these cities are shown in the in Table 1.

Table1 Quota Sampling Calculation Table

\begin{tabular}{|c|c|c|c|c|}
\hline City & $\begin{array}{c}\text { 2013 Population } \\
\text { Quantities }\end{array}$ & $\begin{array}{c}\text { Population } \\
\text { Ratios }\end{array}$ & Percentages & $\begin{array}{c}\text { No. Of } \\
\text { Questionnaires }\end{array}$ \\
\hline Istanbul & 14.160 .467 & 0,608617 & $61 \%$ & 610 \\
\hline Ankara & 5.045 .083 & 0,216838 & $22 \%$ & 220 \\
\hline Izmir & 4.061 .074 & 0,174545 & $17 \%$ & 170 \\
\hline Totals & $\mathbf{2 3 . 2 6 6 . 6 2 4}$ & & $\mathbf{1 0 0 \%}$ & $\mathbf{1 0 0 0}$ \\
\hline
\end{tabular}

Source: www.tuik.gov.tr

Before the gathering of data for the study; a pilot study was conducted over 100 people in order to test the understandability and clarity of the questions as well as to finalize the content of the questionnaire. The questionnaire was conducted face to face. Within the scope of application, 1450 surveys were sent to participants. Only 1000 of the surveys had feedback from the participants. Survey participation feedback percentage is $69 \%$. The demographic layout of the participants are shown in Table 2 below.

Table 2 Demographic Specifications

\begin{tabular}{|c|c|c|c|c|c|c|c|}
\hline \multicolumn{2}{|c|}{$\begin{array}{l}\text { Demographic } \\
\text { Specifications }\end{array}$} & \multirow{2}{*}{$\begin{array}{c}\text { Frequency } \\
385 \\
\end{array}$} & \multirow{2}{*}{$\begin{array}{c}\text { Percentage } \\
38,5 \\
\end{array}$} & \multicolumn{2}{|c|}{$\begin{array}{l}\text { Demographic } \\
\text { Specifications }\end{array}$} & \multirow{2}{*}{$\begin{array}{c}\text { Frequency } \\
699 \\
\end{array}$} & \multirow{2}{*}{$\frac{\text { Percentage }}{69,9}$} \\
\hline \multirow{3}{*}{ 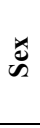 } & Female & & & \multirow{3}{*}{ 㺼 } & Married & & \\
\hline & Male & 615 & 61,5 & & Single & 301 & 30,1 \\
\hline & Total & 1000 & 100 & & Total & 1000 & 100 \\
\hline \multirow{6}{*}{$\stackrel{80}{4}$} & $18-25$ & 119 & 11,9 & \multirow{6}{*}{$\begin{array}{l}\stackrel{\Xi}{\Xi} \\
\stackrel{\Xi}{\Xi}\end{array}$} & $\begin{array}{c}\text { Less than TL } \\
1500 \\
\end{array}$ & 54 & 5,4 \\
\hline & $26-35$ & 312 & 31,2 & & $1500-3000$ & 241 & 24,1 \\
\hline & $36-45$ & 296 & 29,6 & & $3001-4500$ & 270 & 27 \\
\hline & $46-55$ & 253 & 25,3 & & $4501-6000$ & 204 & 20,4 \\
\hline & $\begin{array}{l}56 \text { and } \\
\text { above }\end{array}$ & 20 & 2 & & $\begin{array}{c}\text { More than TL } \\
6000\end{array}$ & 231 & 23,1 \\
\hline & Total & 1000 & 100 & & Total & 1000 & 100 \\
\hline
\end{tabular}




\begin{tabular}{|c|c|c|c|c|c|c|c|}
\hline \multirow{7}{*}{ 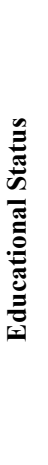 } & $\begin{array}{l}\text { Primary } \\
\text { School }\end{array}$ & 9 & 0,9 & \multirow{7}{*}{ 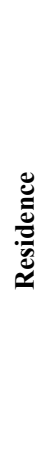 } & \multirow{2}{*}{ Istanbul } & \multirow{2}{*}{610} & \multirow{2}{*}{61} \\
\hline & $\begin{array}{l}\text { High } \\
\text { School }\end{array}$ & 72 & 7,2 & & & & \\
\hline & $\begin{array}{c}\text { Under } \\
\text { Graduate }\end{array}$ & 78 & 7,8 & & \multirow{2}{*}{ Ankara } & \multirow{2}{*}{220} & \multirow{2}{*}{22} \\
\hline & University & 496 & 49,6 & & & & \\
\hline & $\begin{array}{c}\text { Post } \\
\text { Graduate }\end{array}$ & 345 & 34,5 & & \multirow{2}{*}{ Izmir } & \multirow{2}{*}{170} & \multirow{2}{*}{17} \\
\hline & \multirow[t]{2}{*}{ Total } & \multirow[t]{2}{*}{1000} & \multirow[t]{2}{*}{100} & & & & \\
\hline & & & & & Total & 1000 & 100 \\
\hline
\end{tabular}

Of the participants; $38.5 \%$ are women; $61.5 \%$ are men; $69.9 \%$ are married; $30.1 \%$ are single. Of the participants; $11.9 \%$ are between the ages of $18-25 ; 31.2 \%$ are between $26-35 ; 29.6 \%$ are between $36-45 ; 25.3 \%$ are between $46-55$; and $2 \%$ are 56 years old or above. Looking at the educational status of the participants; $0.9 \%$ are primary school graduates; $71 \%$ are high school graduates; $7.8 \%$ are undergraduates; $49.6 \%$ are university graduates; and $34.5 \%$ are post graduates. Of the participants; $5.4 \%$ is earning less than TL $1500 ; 24.1 \%$ is earning between TL $1500-3000 ; 27 \%$ is earning between TL $3001-4500 ; 20.4 \%$ is earning between $4501-6000$; and $23.1 \%$ is earning more than TL 6000. Of the participants; $61 \%$ is living in Istanbul; $22 \%$ is living in Ankara; and $17 \%$ is living in Izmir. The majority of the questionnaire participants are married, male, between the 36-45 year old age frame, university graduates, earning between TL 30014500 monthly, and living in Istanbul. Of the participants; $17.9 \%$ are HP brand computer owners; $11.8 \%$ are Asus owners; $11.4 \%$ are Toshiba owners; and 10.1\% are Samsung owners.

\subsection{Measurement Tools}

The information related to the measurement tools are shown in Table 3 below.

Table 3 Variables and Codes Used in the Scales

\begin{tabular}{|c|c|c|c|c|}
\hline \multicolumn{2}{|c|}{ Scales } & Dimensions and Codes & $\begin{array}{l}\text { Number of } \\
\text { statements }\end{array}$ & Source \\
\hline \multirow{4}{*}{ 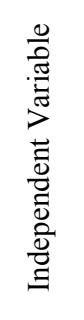 } & \multirow{4}{*}{ 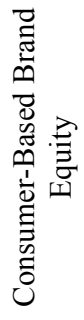 } & Brand Awareness (M_F) & 6 & \multirow{4}{*}{$\begin{array}{l}\text { Lassar, Mittal and Sharma (1995), } \\
\text { Aaker (1996), Yoo, Donthu and Lee } \\
\text { (2000), Netemeyer et al., (2004), } \\
\text { Pappu, Quester and Cooksey (2005, } \\
\text { 2006) }\end{array}$} \\
\hline & & Brand Association (M_C) & 7 & \\
\hline & & Perceived Quality (A_K) & 6 & \\
\hline & & Brand Loyalty (M_S) & 6 & \\
\hline \multirow{2}{*}{ 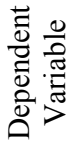 } & \multirow{2}{*}{$\sum_{0}^{1}$} & Positive WOM (P_W) & 5 & \multirow{2}{*}{$\begin{array}{l}\text { Godes and Mayzlin (2004), Goyette et } \\
\text { al., (2010), Samutachak and Li (2012) }\end{array}$} \\
\hline & & Negative WOM (N_W) & 5 & \\
\hline 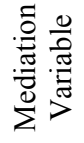 & \multicolumn{2}{|r|}{ Brand Preference (M_T) } & 5 & Chang and Liu (2009) \\
\hline
\end{tabular}

As seen on the table, the independent variable is comprised of 4 sub dimensions with 25 statements, the dependent variable is comprised of 2 sub dimensions with 10 
statements, and the mediation variable is comprised of a single sub dimension with 5 statements. As such, in addition to these 40 statements above, the scale is comprised of 47 statements with the additional 7 statements related with the demographic data. The participants are requested to respond to the questions in a quintet Likert Scale. ( $1=$ Strongly disagree, $5=$ Strongly agree)

\subsection{Testing of Scales Used in Research}

The exploratory and confirmatory factor analysis regarding the validity and reliability of the scales used in research are listed below.

\subsubsection{Exploratory Factor Analysis}

Exploratory factor analysis is materialized with principal components and variamax rotation. Analysis is performed by removing weak loads that are below the factor variance, which is 0,30 , and 14 statements which are loaded by two factors at once during the analysis process. Statements related to factor groups emerged from factor analysis, factor loads, explained variances of factors, and Cronbach Alpha indexes shown in Table 4.

Tablo 4 Factor Loads Calculated using Varimax Rotation

\begin{tabular}{|c|c|c|c|}
\hline Statements & $\begin{array}{l}\text { Factor } \\
\text { Load }\end{array}$ & $\begin{array}{c}\text { Explained } \\
\text { Variance }(\%) \\
\end{array}$ & $\begin{array}{l}\text { Cronbach } \\
\text { Alfa }\end{array}$ \\
\hline Brand Awareness & & 6,877 & 0,78 \\
\hline $\begin{array}{l}\text { This is the first brand that comes to mind when I think } \\
\text { about computers }\end{array}$ & 0,692 & & \\
\hline $\begin{array}{l}\text { I can easily reconginze this brand among the other } \\
\text { computer brands }\end{array}$ & 0,806 & & \\
\hline $\begin{array}{l}\text { I hear about promotions and advertisements of this } \\
\text { brand }\end{array}$ & 0,778 & & \\
\hline $\begin{array}{l}\text { I was informed about the company and services } \\
\text { provided, before I purchased the product }\end{array}$ & 0,787 & & \\
\hline Brand Association & & 11,618 & 0,92 \\
\hline I associated this brand with difference & 0,752 & & \\
\hline I associated this brand with innovation & 0,731 & & \\
\hline I associated this brand with power & 0,744 & & \\
\hline This brand is different from its rivals & 0,603 & & \\
\hline Percived Quality & & 16,998 & 0,93 \\
\hline This brand has high quality & 0,669 & & \\
\hline Quality of this brand meets my expectations & 0,771 & & \\
\hline $\begin{array}{l}\text { I'd always trust this brand if I wanted to buy a high- } \\
\text { end computer }\end{array}$ & 0,722 & & \\
\hline $\begin{array}{l}\text { I believe that this brand will keep its level of quality in } \\
\text { future }\end{array}$ & 0,726 & & \\
\hline This brand has high functional features & 0,694 & & \\
\hline Brand Loyalty & & 20,056 & 0,87 \\
\hline
\end{tabular}




\begin{tabular}{|l|c|c|c|}
\hline I think I'm loyal to this brand & 0,744 & & \\
\hline I always buy this brand & 0,733 & & \\
\hline $\begin{array}{l}\text { I pay more higher prices for this brand instead of other } \\
\text { brands that have equal quaility }\end{array}$ & 0,772 & & \\
\hline Positive WOM & & 7,061 & 0,90 \\
\hline I recommend this brand & 0,528 & & \\
\hline I promote brand's positive features & 0,750 & & \\
\hline I mostly say positive things about this brand & 0,613 & & \\
\hline Negeative WOM & & 9,616 & \\
\hline $\begin{array}{l}\text { My opinions about this brand are more negative than } \\
\text { they are positive }\end{array}$ & $-0,854$ & & \\
\hline I mostly say negative things about this brand & $-0,871$ & & \\
\hline I don't speak highly of this brand & $-0,754$ & & \\
\hline Brand Preference & & 6,254 & \\
\hline I prefer this brand & 0,537 & & \\
\hline I prefer this brand over other computer brands & 0,652 & Sig. & \\
\hline $\begin{array}{l}\text { I prefer this brand over other computer brands, even if } \\
\text { other brands' products have superior features }\end{array}$ & 0,790 & & \\
\hline $\begin{array}{l}\text { I prefer this brand over other computer brands, even if } \\
\text { other brands have better offers }\end{array}$ & 0,850 & & \\
\hline \multicolumn{1}{|c|}{ Kaiser Meyer Olkin Measure of Sampling Adequacy. } & $\begin{array}{l}0,965 \\
\text { Approx. } \\
\text { Bartlett's Test of Sphericity }\end{array}$ & \\
\hline & & 21350,810 \\
\hline
\end{tabular}

$78,481 \%$ of the total variance is explained by the "7 factors model". When the factor loads are examined, it is seen that all 7 factors are bigger than the 0,30 threshold that is valid on social sciences. In stated factor loads, the minimum value is 0,528 and the maximum value is 0,871 . There are great differences between related factor loads and other factor loads of a variable. Acquired datas show that requirements of scructure and separation of the "7 factors model" are met.

Cronbach alfa indexes are calculated with the SPSS Statistics 21 program for scale reliability. Alpha indexes in table 4 shows that all indexes are above 0,70 . Acquired data shows that the scale is reliable.

\subsubsection{Confirmatory Factor Analysis}

To test the validity of the scales the SPSS AMOS 21 program was used; for consumer-based brand equity and WOM scale the first level is employed, while for the brand preference scale, single factored confirmatory factor analysis is employed. Necessary modifications developed by the program, concerning the concordance values of the scale models, were applied to test the validities of the scales, since they were not 
within the limits of the accepted values. The amendments made in the scales after the modifications and the concordance values produced by the scale models are shown respectively in Table 5 and 6.

Table 5 The Amendments Made in the Scale

\begin{tabular}{|c|c|c|c|c|}
\hline \multicolumn{2}{|l|}{ Scale } & Dimension & $\begin{array}{c}\text { No. Of } \\
\text { Statements }\end{array}$ & $\begin{array}{c}\text { No. Of Excepted } \\
\text { Statements }\end{array}$ \\
\hline \multirow{4}{*}{$\begin{array}{c}\text { Independent } \\
\text { Variable }\end{array}$} & \multirow{4}{*}{$\begin{array}{c}\text { Consumer- } \\
\text { Based Brand } \\
\text { Equity }\end{array}$} & Brand Awareness & 6 & 2 \\
\hline & & Brand Association & 7 & 3 \\
\hline & & Perceived Quality & 6 & 1 \\
\hline & & Brand Loyalty & 6 & 3 \\
\hline \multirow{2}{*}{ Dependent Variable } & \multirow{2}{*}{ WOM } & Positive WOM & 5 & 2 \\
\hline & & Negative WOM & 5 & 2 \\
\hline Mediation Variable & \multicolumn{2}{|c|}{ Brand Preference } & 5 & 1 \\
\hline
\end{tabular}

As seen in the Table 514 statements were accepted from the scale in total.

Table 6 Concordance Values of the Scales

\begin{tabular}{|c|c|c|c|c|c|c|}
\hline & $\mathbf{X}^{\mathbf{2}}$ & $\mathbf{d f}$ & $\mathbf{X}^{\mathbf{2}} / \mathbf{d f}$ & GFI & CFI & RMSEA \\
\hline $\begin{array}{c}\text { Consumer-Based Brand } \\
\text { Equity Scale }\end{array}$ & 470,475 & 98 & 4,801 & 0,94 & 0,97 & 0,062 \\
\hline WOM Scale & 39,358 & 8 & 4,920 & 0,99 & 0,99 & 0,063 \\
\hline Brand Preference Scale & 1,373 & 1 & 1,373 & 0,99 & 0,99 & 0,019 \\
\hline $\begin{array}{c}\text { Good Concordance } \\
\text { Values* }\end{array}$ & & & $\leq \mathbf{3}$ & $\geq \mathbf{0 , 9 0}$ & $\geq \mathbf{0 , 9 7}$ & $\leq \mathbf{0 , 0 5}$ \\
\hline $\begin{array}{c}\text { Acceptable Concordance } \\
\text { Values* }\end{array}$ & & $\leq 4-5$ & $\mathbf{0 , 8 9 - 0 , 8 5}$ & $\geq \mathbf{0 , 9 5}$ & $\mathbf{0 , 0 6 - 0 , 0 8}$ \\
\hline
\end{tabular}

$\mathrm{p}>.05, \mathrm{X}^{2}=$ Chi-Square; $\mathrm{df}=$ Degree of Freedom; GFI=Goodness Of Fit Index; CFI=Comparative Fit Index; RMSEA=Root Mean Square Error of Approximation.

"Source: Meydan, C.H. and Şeşen, H. (2011). Yapısal Eşitlik Modellemesi AMOS Uygulamaları. Ankara: Detay Yayıncılık, p.37.

Since the values in Table 6 are in acceptable limits, the 4 factor structure of consumer-based brand equity, 2 factor structure of WOM, and single factor structure of brand equity are verified.

Average variance extracted values (AVE) which have been calculated with the reference to the method recommended by Fornell and Larcker (1981) to investigate the convergent validity of the scales and composite reliability (CR) values are shown in Table 7.

Table 7 The Outcomes of the Meausurment Model

\begin{tabular}{|c|c|c|c|c|}
\hline \multirow{2}{*}{ Factor } & Codes & Factor Load & $\begin{array}{c}\text { Average Variance } \\
\text { Extracted (AVE) }\end{array}$ & $\begin{array}{c}\text { Composite Reliability } \\
\text { (CR) }\end{array}$ \\
\hline \multirow{3}{*}{$\begin{array}{c}\text { Brand } \\
\text { Awareness }\end{array}$} & MF1 & 0,70 & & \\
\cline { 2 - 3 } & MF2 & 0,66 & 0,466 & 0,777 \\
\cline { 2 - 3 } & MF5 & 0,69 & & \\
\cline { 2 - 3 } $\begin{array}{c}\text { Brand } \\
\text { Association }\end{array}$ & MF6 & 0,68 & & \multirow{2}{*}{0,921} \\
\cline { 2 - 3 } & MC5 & 0,88 & 0,746 & \\
\cline { 2 - 3 } & MC6 & 0,89 & & \\
\hline
\end{tabular}




\begin{tabular}{|c|c|c|c|c|}
\hline & MC7 & 0,79 & & \\
\hline \multirow{5}{*}{$\begin{array}{c}\text { Percieved } \\
\text { Quality }\end{array}$} & AK2 & 0,86 & \multirow{5}{*}{0,727} & \multirow{5}{*}{0,930} \\
\hline & AK3 & 0,81 & & \\
\hline & AK4 & 0,89 & & \\
\hline & AK5 & 0,85 & & \\
\hline & AK6 & 0,85 & & \\
\hline \multirow{3}{*}{$\begin{array}{l}\text { Brand } \\
\text { Loyalty }\end{array}$} & MS1 & 0,85 & \multirow{3}{*}{0,695} & \multirow{3}{*}{0,872} \\
\hline & MS4 & 0,86 & & \\
\hline & MS5 & 0,79 & & \\
\hline \multirow{3}{*}{$\begin{array}{l}\text { Positive } \\
\text { Wom }\end{array}$} & PW1 & 0,90 & \multirow{3}{*}{0,753} & \multirow{3}{*}{0,901} \\
\hline & PW2 & 0,81 & & \\
\hline & PW3 & 0,89 & & \\
\hline \multirow{3}{*}{$\begin{array}{l}\text { Negative } \\
\text { Wom }\end{array}$} & NW2 & 0,79 & \multirow{3}{*}{0,628} & \multirow{3}{*}{0,833} \\
\hline & NW4 & 0,90 & & \\
\hline & NW5 & 0,67 & & \\
\hline \multirow{4}{*}{$\begin{array}{c}\text { Brand } \\
\text { Preference }\end{array}$} & MT1 & 0,83 & \multirow{4}{*}{0,665} & \multirow{4}{*}{0,887} \\
\hline & MT2 & 0,95 & & \\
\hline & MT3 & 0,76 & & \\
\hline & MT4 & 0,70 & & \\
\hline
\end{tabular}

When the values in the table are analyzed, it can be stated that the convergent validity of the scales has been provided.

\section{Findings}

\subsection{Correlation Findings}

Average scores of the scales, standard deviations, and correlation values among the variables are presented in Table 8 . There appeared meaningful relationship among the variables according to the findings achieved.

Table 8 Correlations For the Variables

\begin{tabular}{|c|c|c|c|c|c|c|c|c|c|}
\hline & $\stackrel{\bar{\Xi}}{\Sigma}$ & 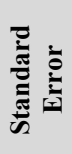 & 离 & 竎 & 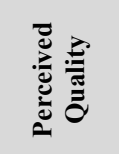 & 昰 & $\begin{array}{l}\sum_{\overline{0}} \sum_{0} \\
0 \\
0\end{array}$ & 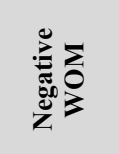 & 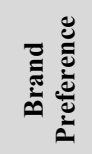 \\
\hline Brand Awareness & 3,37 & ,93 & $(0,68)$ & & & & & & \\
\hline $\begin{array}{c}\text { Brand } \\
\text { Association }\end{array}$ & 3,40 & ,99 & $0,698^{* *}$ & $(0,86)$ & & & & & \\
\hline Perceived Quality & 3,67 & ,91 & $0,642^{* *}$ & $0,748^{* *}$ & $(0,85)$ & & & & \\
\hline Brand Loyalty & 2,88 & 1,07 & $0,571^{* *}$ & $0,670^{* *}$ & $0,640^{* *}$ & $(0,83)$ & & & \\
\hline Positive WOM & 3,64 & ,91 & $0,566^{* *}$ & $0,675^{* *}$ & $0,812^{* *}$ & $0,596^{* *}$ & $(0,87)$ & & \\
\hline Negative WOM & 2,36 & ,91 & $-0,236^{* *}$ & $-0,290^{* *}$ & $-0,457^{* *}$ & $-0,287^{* *}$ & $-0,455^{* *}$ & $(0,79)$ & \\
\hline Brand Preference & 3,03 & 1,04 & $0,607^{* *}$ & $0,698^{* *}$ & $0,719^{* *}$ & $0,821^{* *}$ & $0,700^{* *}$ & $-0,344^{* *}$ & $(0,81)$ \\
\hline
\end{tabular}

$* * \mathrm{p}<0.01 \mathrm{~N}=(1000)$

The values in parentheses in the table are the values of the square root of the variance explained on an average for each construct. If these values are greater than the correlation values in its own line and column, discriminant validity is discussed 
(Fornell and Larcker, 1981). Examining the values in the table, it is derived that the separation effect is provided.

\subsection{Structural Equation Modeling}

In order to test the hypothesis of the research, the structural equation model established between the independent variable of the research, the consumer-based brand equity, and the dependent variable WOM is presented in Figure 2.

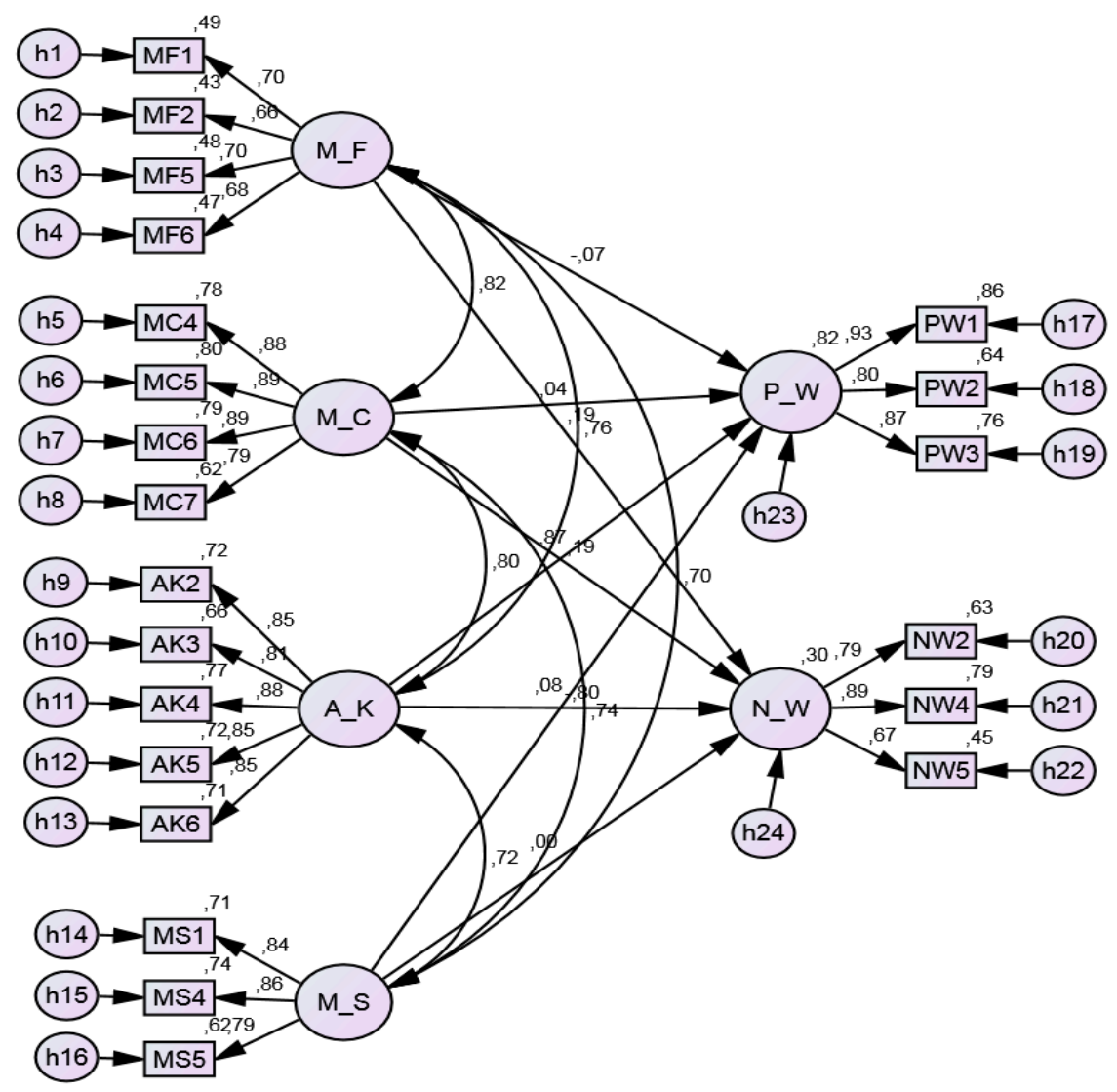

Figure 2 Structural Equation Model Established Between the Consumer-Based Brand Equity and WOM

The concordance values of the model depicted in Figure 2 are shown in Table 9. The values in the table provide sufficient evidence that the concordance values of the established model are in the acceptable limits and the model is structurally appropriate.

Table 9 The Concordance Values of Structural Equation Model Established Between the Consumer-Based Brand Equity and the WOM

\begin{tabular}{|c|c|c|c|c|c|c|}
\hline & $\mathbf{X}^{\mathbf{2}}$ & $\mathbf{d f}$ & $\mathbf{X}^{\mathbf{2}} / \mathbf{d f}$ & $\mathbf{G F I}$ & CFI & RMSEA \\
\hline Concordance Values & $\mathbf{7 8 4 , 7 1 8}$ & $\mathbf{1 9 5}$ & $\mathbf{4 , 0 2 4}$ & $\mathbf{0 , 9 3}$ & $\mathbf{0 , 9 6}$ & $\mathbf{0 , 0 5 5}$ \\
\hline $\begin{array}{c}\text { Good Concordance } \\
\text { Values }\end{array}$ & & & $\leq 3$ & $\geq 0,90$ & $\geq 0,97$ & $\leq 0,05$ \\
\hline $\begin{array}{c}\text { Acceptable } \\
\text { Concordance Values }\end{array}$ & & & $\leq 4-5$ & $0,89-0,85$ & $\geq 0,95$ & $0,06-0,08$ \\
\hline
\end{tabular}

$\mathrm{p}>.05, \mathrm{X}^{2}=$ Chi-Square; df=Degree of Freedom; GFI=Goodness Of Fit Index; CFI=Comparative Fit Index; RMSEA=Root Mean Square Error of Approximation. 
* Source: Meydan, C.H. and Şeşen, H. (2011). Yapısal Eşitlik Modellemesi AMOS Uygulamaları. Ankara: Detay Yayınc1lık, p.37.

$\beta$ quotients between the variables according to the established model, standard error, and $\mathrm{p}$ values are provided in Table 10 .

Table 10 The Quoitents of the Structural Equity Model Established Between the Consumer-Based Brand Equity and the WOM

\begin{tabular}{|l|c|c|c|}
\hline \multicolumn{1}{|c|}{ Variables } & $\boldsymbol{\beta}$ & $\begin{array}{c}\text { Standard } \\
\text { Error }\end{array}$ & p \\
\hline Brand Awareness - Positive WOM & $-0,07$ & 0,053 & $\mathbf{0 , 1 4 4}$ \\
\hline Brand Awareness - Negative WOM & 0,19 & 0,077 & 0,017 \\
\hline Brand Association - Positive WOM & 0,04 & 0,052 & $\mathbf{0 , 4 1 8}$ \\
\hline Brand Association - Negative WOM & 0,19 & 0,075 & 0,018 \\
\hline Perceived Quality - Positive WOM & 0,87 & 0,048 & $* * *$ \\
\hline Perceived Quality - Negative WOM & $-0,80$ & 0,067 & $* * *$ \\
\hline Brand Loyalty - Positive WOM & 0,08 & 0,033 & 0,031 \\
\hline Brand Loyalty - Negative WOM & 0,01 & 0,048 & $\mathbf{0 , 9 4 9}$ \\
\hline
\end{tabular}

Looking at the values acquired, since $p>0,05$ in the relations of the brand awareness and brand association with the positive WOM as well as that of brand loyalty with negative WOM, it is derived that there is no statistically meaningful relationship.

It is also resulted that there is an effect of brand awareness on negative WOM $(\beta=0,19 ; p<0,05)$, of brand association on negative WOM $(\beta=0,19 ; p<0,05)$, of perceived quality on positive $\operatorname{WOM}(\beta=0,87 ; \mathrm{p}<0,05)$ and on negative WOM $(\beta=-0,80 ; p<0,05)$, and finally of brand loyalty on positive $\operatorname{WOM}(\beta=0,08 ; p<0,05)$. The results of the hypothesis in accordance with these findings are provided in Table 11.

Table 11 Hypothesis Results of The Research Model

\begin{tabular}{|l|c|}
\hline \multicolumn{1}{|c|}{ Hypothesis } & Result \\
\hline $\begin{array}{l}\mathbf{H}_{\mathbf{1}}: \text { There is a significant relationship between brand awareness and the } \\
\text { positive WOM }\end{array}$ & Not Supported \\
\hline $\begin{array}{l}\mathbf{H}_{\mathbf{2}}: \text { There is a significant relationship between brand awareness and the } \\
\text { negative WOM }\end{array}$ & Supported \\
\hline $\begin{array}{l}\mathbf{H}_{\mathbf{3}}: \text { There is a significant relationship between brand association and the } \\
\text { positive WOM }\end{array}$ & Not Supported \\
\hline $\begin{array}{l}\mathbf{H}_{\mathbf{4}}: \text { There is a significant relationship between brand association and the } \\
\text { negative WOM }\end{array}$ & Supported \\
\hline $\begin{array}{l}\mathbf{H}_{5}: \text { There is a significant relationship between perceived quality and the } \\
\text { positive WOM }\end{array}$ & Supported \\
\hline $\begin{array}{l}\mathbf{H}_{\mathbf{6}}: \text { There is a significant relationship between perceived quality and the } \\
\text { negative WOM }\end{array}$ & Supported \\
\hline $\begin{array}{l}\mathbf{H}_{7}: \text { There is a significant relationship between brand loyalty and the } \\
\text { positive WOM }\end{array}$ & Supported \\
\hline $\begin{array}{l}\mathbf{H}_{\mathbf{8}}: \text { There is a significant relationship between brand loyalty and the } \\
\text { negative WOM }\end{array}$ & Not Supported \\
\hline
\end{tabular}

Looking at the $\mathrm{R}^{2}$ values acquired about the model, it is understood that $82 \%$ of the positive WOM dimension along with $30 \%$ of its negative dimension of the WOM variable, which is the dependent variable of the research, can be explained by the consumer-based brand equity, which is the independent variable of the research. 


\subsection{Test of Mediation Effect by the Structural Equation Model}

The mediation role of the brand preference in the relation between the consumerbased brand equity and WOM was tested by a three-phase method provided by Baron and Kenny (1986). According to the authors, it is necessary that three phases be realized in order to mention a mediation role. In the first phase, there should be an effect of the independent variable (consumer-based brand equity) on the dependent variable (WOM). In the second phase, it is required that the independent variable (consumer-based brand equity) should have an effect on the mediation variable (brand preference). Finally in the third phase, when the mediation variable (brand preference) is added into the model, there should exist a meaningful effect of the mediation variable (brand preference) on the dependent variable (WOM) as the effect of the independent variable (consumerbased brand equity) on the dependent variable (WOM) decreases.

The determination of the effects of the independent variable on the dependent variable, as was proposed by the authors for the first phase, were identified and provided in figure 2 . The equation model established for the application of the second and third phases are also presented in Figure 3.

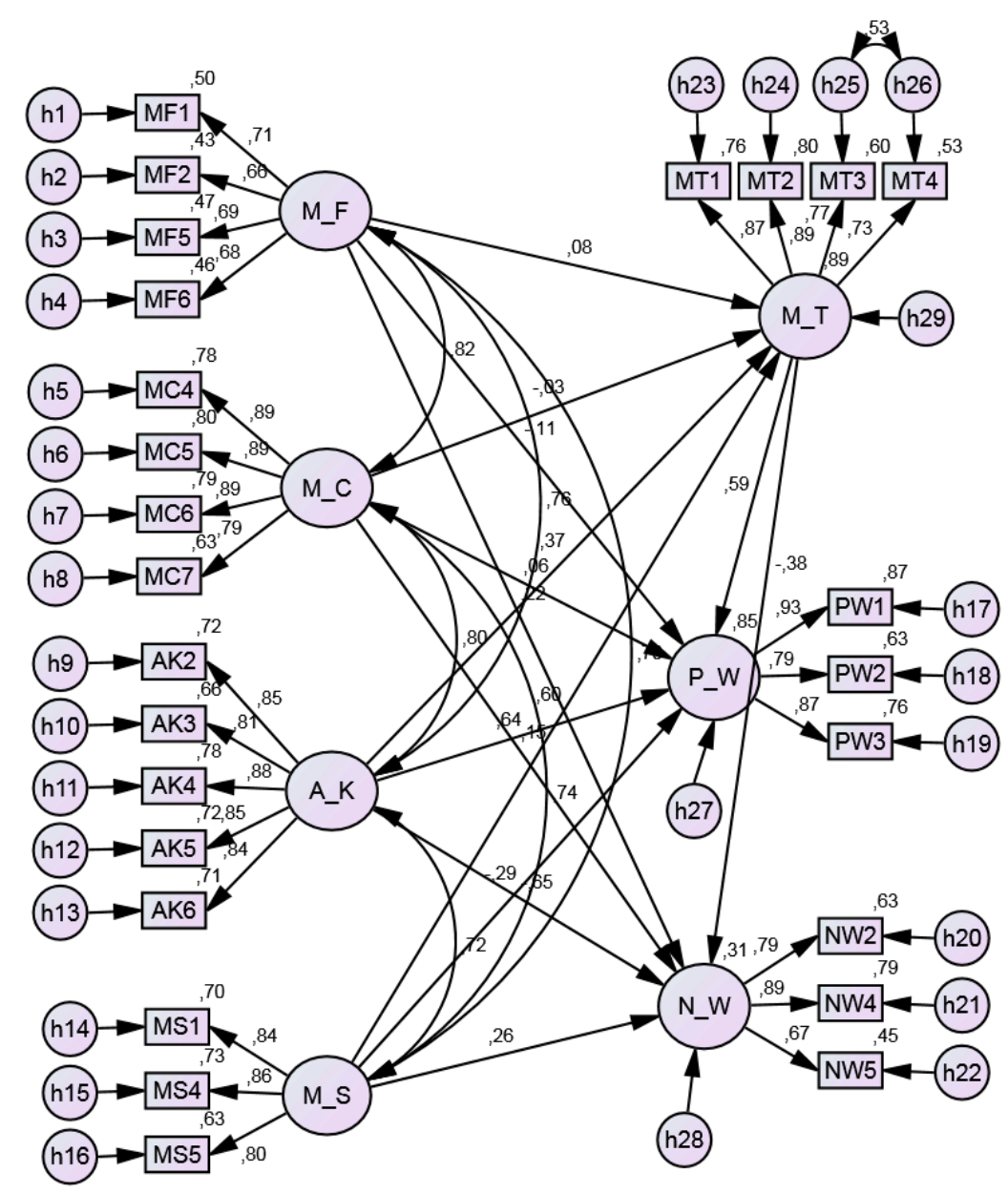

Figure 3 The Structural Equation Model Established To Measure The Influence Of Mediation Effect 
The concordance values of the model in the Figure 3 are shown in the Table 12. The values in the table provide sufficient evidence that the concordance values of the established model are in the acceptable limits and the model is structurally appropriate.

Table 12 The Concordance Values Of The Model Established To Measure The Effects Of The Structural Equation Model

\begin{tabular}{|c|c|c|c|c|c|c|}
\hline & $\mathbf{X}^{\mathbf{2}}$ & $\mathbf{d f}$ & $\mathbf{X}^{2} / \mathbf{d f}$ & $\mathbf{G F I}$ & $\mathbf{C F I}$ & RMSEA \\
\hline Concordance Values & $\mathbf{1 2 8 0 , 4 6 1}$ & $\mathbf{2 7 8}$ & $\mathbf{4 , 6 0 6}$ & $\mathbf{0 , 9 0}$ & $\mathbf{0 , 9 5}$ & $\mathbf{0 , 0 6 0}$ \\
\hline $\begin{array}{c}\text { Good Concordance } \\
\text { Values }\end{array}$ & & & $\leq 3$ & $\geq 0,90$ & $\geq 0,97$ & $\leq 0,05$ \\
\hline $\begin{array}{c}\text { Acceptable Concordance } \\
\text { Values }\end{array}$ & & & $\leq 4-5$ & $0,89-0,85$ & $\geq 0,95$ & $0,06-0,08$ \\
\hline
\end{tabular}

$\mathrm{p}>.05, \mathrm{X}^{2}=$ Chi-Square; $\mathrm{df}=$ Degree of Freedom; GFI=Goodness Of Fit Index; CFI=Comparative Fit Index; RMSEA=Root Mean Square Error of Approximation.

* Source: Meydan, C.H. and Şeşen, H. (2011). Yapısal Eşitlik Modellemesi AMOS Uygulamaları. Ankara: Detay Yayınc1lik, p.37.

$\beta$ quotients, standard error, and $p$ values among the variables according to the established model are shown in Table 13.

Table 13 The Quoitents Of The Structural Equation Model Established To Measure The Influences Of The Mediation Effects

\begin{tabular}{|l|c|c|c|}
\hline \multicolumn{1}{|c|}{ Variables } & $\boldsymbol{\beta}$ & $\begin{array}{c}\text { Standard } \\
\text { Error }\end{array}$ & p \\
\hline Brand Awareness - Brand Preference & 0,08 & 0,051 & $\mathbf{0 , 0 6 8}$ \\
\hline Brand Association - Brand Preference & $-0,03$ & 0,049 & $\mathbf{0 , 4 9 2}$ \\
\hline Perceived Quality - Brand Preference & 0,37 & 0,042 & $* * *$ \\
\hline Brand Loyalty - Brand Preference & 0,60 & 0,036 & $* * *$ \\
\hline Brand Preference - Positive WOM & 0,59 & 0,091 & $* * *$ \\
\hline Brand Preference - Negative WOM & $-0,38$ & 0,122 & 0,007 \\
\hline Brand Awareness - Positive WOM & $-0,11$ & 0,054 & 0,021 \\
\hline Brand Awareness - Negative WOM & 0,22 & 0,079 & 0,008 \\
\hline Brand Association - Positive WOM & 0,06 & 0,052 & $\mathbf{0 , 1 8 0}$ \\
\hline Brand Association - Negative WOM & 0,15 & 0,076 & $\mathbf{0 , 0 6 0}$ \\
\hline Perceived Quality - Positive WOM & 0,64 & 0,059 & $* * *$ \\
\hline Perceived Quality - Negative WOM & $-0,65$ & 0,084 & $* * *$ \\
\hline Brand Loyalty - Positive WOM & 0,29 & 0,067 & $* * *$ \\
\hline Brand Loyalty - Negative WOM & 0,26 & 0,091 & 0,019 \\
\hline
\end{tabular}

Looking at the values achieved, there is no statistically meaningful relationship since $p>0,05$ in the relations of brand preference, which is the mediation variable with the sub dimensions of consumer-based brand equity, an independent variable, and with brand awareness and brand association. However since $\mathrm{p}<0,05$ in the relation of perceived quality and brand loyalty, which are the two level sub dimensions of consumer-based brand equity with the brand preference which is the mediation variable, it can be referred that the mentioned two dimensions has effects on the brand preference. As such, the second phase of Baron and Kenny (1986) can be partially 
achieved. In this case, it was deemed necessary to continue with the third phase in order to identify the influence of the mediation effect.

The value of $\beta=0,87$ is decreased to $\beta=0,64$ in the effects of consumer-based brand equity (in its perceived quality dimension) on the positive WOM and that of $\beta=-0,80$ to $\beta=-0,65$ for the negative WOM. There observed no decrease in the $\beta$ value of the other sub dimension, which is brand loyalty. Since $p<0,05$ in the relation of brand preference with both positive and negative WOM simultaneously, there again observed meaningful effect of brand preference on WOM.

When the mediation variable is added into the model, the decrease in the $\beta$ quotients, which represents the decrease in the effects of the independent variable on the dependent variable, as well as the meaningful effects of the mediation variable on the dependent variable, explain the mediation effect. Henceforth, since the third phase of Baron and Kenny (1986) are realized and the mediation effect is such verified, the 9th and last hypothesis of the research $\left(\mathbf{H}_{\mathbf{9}}\right.$ : There is a mediation role of the brand preference between the relation of consumer-based brand equity and WOM.) is partially supported.

\section{Conclusion}

In the light of these findings attained, it may be referred that; the consumer-based brand equity is existent, in this existence of the brand equity there is a more prominent presence, with regard to the WOM of perceived quality and brand loyalty dimensions than that of the dimensions of brand awareness and brand association, and finally the brand equity attained, can explain the positive dimension of WOM up to a considerable percentage, like $82 \%$.

With regard to the consumers, it is derived that the factors such as; the meeting of the consumer expectations of the brand, a perception for high quality, the reliance on the future continuation of the product quality, the reliance towards the brand and the consumers' acceptance of a tie towards the brand, etc. are mobilizing the consumers toward the WOM. As such, the consumers are transmitting their positive emotions and ideas to their circles of friends and families in every social occasion they participate. It may also be referred that concerning the product range of high technology, like computers, the brand can be spread very fast by WOM and the positive usage experiences of the consumers will have a dominant effect on the purchasing decisions of the other customers. The usage experiences transmitted to them from other people will easily convince the customers since they do not fully rely on a sales aim.

The ideas of consumers, who have used a computer with satisfaction, on purchasing the same brand again when needed, will affect the other people around. Thus the company producing this brand will have chance to reach more customers and achieve an even greater number of sales by benefiting from positive feelings towards the product, along with the advertisement made by such loyal customers without suffering any additional cost at all.

In addition with the results attained so far, it is also referred that the consumerbased brand equity is beyond sufficiency in explaining the negative effects of WOM. As such, regarding the even increased level of explanatory effect of the negative dimension of WOM along with the brand equity in connection with some different factors like; price, distribution channel, advertisement, promotion, and post-sales services, further 
studies may be regarded necessary which are beyond the scope of this study as of current aims and objectives.

\section{Managerial Effects}

The proposals for the high level executives as well as for the marketing and brand managers are listed below depending on the attained data in the conclusion of this study.

- The issues like; the consumers being aware of the brand in the market, the brand being the first associated one in its product range, consumers' awareness, beliefs and ideas on the advertisements and promotions of the brand, their familiarity with the brand and the corporation producing it, their belief on the strength of the brand, their beliefs on the brands' association with its difference, innovation and distinction from the competitors, and so on, are not sufficient by themselves to convince the consumers to purchase this brand. In connection with this, since they will not have an experience on a brand they have never purchased, it is not possible for them to advise and to extend their positive ideas to the other people around them.

- The factors such as: the consumers' ideas on the supremacy of a brand to be the most qualified one in the market, meeting of the brand quality to the expectations of the consumers, the belief that they can rely on this brand and its quality will continue to exist in the future, and so on, are the most important factors for the customer's preferred brand. People preferring a brand because of its quality are transferring the good sides of the brand and recommending and encouraging people to purchase this brand because it is their favorite.

- The customers, having a preferred brand and receiving satisfaction out of it will be the loyal customers of this brand. As such, an emotional tie between the consumer and the brand emerges, which further encourages the purchasing of the same brand all the time without being affected by the marketing efforts of the other brands. This tie may even further encourage the customers to prefer a brand even against the cheaper price of the other equal quality brands.

- It may be referred by these reasons mentioned above that the high level executives, as well as the marketing and brand managers of the companies, should take the sustainable quality and endurance along with necessary functional specifications into account in even more priority, as to establish a strong ties with the customers and turn them into loyal customers of the brand.

The customers of the companies achieving this will extend their positive views on the brand and encourage the people in their circles of friends and family members as a volunteer representer of the brand in any social occasion they participate as well as social media affairs. The company in this process will suffer no cost as it benefits from the easiness and the cheapness of the WOM at the same time. As such, the strong brand value to be inherited along with efficient WOM companies may grab competitive advantage which may help them survive in longer terms. 


\section{Limitations of the Research}

This research investigates the brand preference mediating role between consumer based brand equity and word of mouth marketing in computer industry. Thus, further research needs to be applied in different sectors and different countries. Caution is therefore advisable when generalizing these results to other settings.

Only 1450 computer users living in Istanbul, Ankara, and Izmir have participated in our research. The sampling method is quota sampling, which is a nonprobability sampling method. This limits the generalizability of its results.

The research is limited with the questions in the questionnaire and the answers of the participant consumers. The conclusion and generalizations which are deduced in the light of the findings obtained are only valid within the researched population sample.

The research is cross sectional in nature. The cross-sectional design limits to investigate changes in the research over time.

\section{Recommendations for the Future Researches}

The recommendations for the future researches on the issue are listed below:

- The study is conducted on the computer owners. It is regarded that the study should be furthered on the other segments such as GSM, motor vehicles, and textile.

- It is regarded that if a further research is conducted on the service sector in which the abstract type of products are being provided, there may be different results achieved.

- The research is conducted on the people inhabited in the big cities of Ankara, Istanbul, and Izmir. A further research may be conducted on other people living in different cities of Turkey as well.

- The consumer-based brand equity is dealt under 4 sub dimensions while the WOM is dealt under 2 of them. It is regarded that if the further researches are conducted in different numbers and levels of sub dimensions for the consumerbased brand equity and WOM, the result of such a research may be compared with those of this research as to contribute more into the literature.

- The researcher employed the brand preference as the mediation variable in this research. It is as such regarded that different and more numbers of mediation variables (brand image, customer satisfaction etc.) may be employed, as well as the scales used in this research may be proliferated as to include different scales.

In conclusion; business owners are reaching to consumers using marketing communication activities and creating awareness by placing themselves in a different spot than their rivals by promising offers under brand names. This situation creates an environment that removes the perceived risks regarding the brand, especially in sectors like informatics where the perceived risks are felt on greater scales. However, the situation explained above is not always enough to make the consumers decide to buy the product. What really matters at the decision point is that the promises are supported 
by the perceived quailty of brand and by people who actually experienced this perception. Positive opinions of a respected acquaintance is often the most important factor in making the decision of whether to buy the product, while negative opinions about the brand will reduce the level of interest towards the brand. With positive opinions from consumers that have experienced the brand products, business owners would be able to persuade the consumers that they reached through promotional activities like advertisement, personal sales, sale development, etc. but unable to persuade the consumers to buy the product. With this, they will find opportunity to conduct sales in a much larger range. Consumers that experience what product the brand suggests and is satisfied with them, will become loyal customers of the brand. This loyalty will guarantee future sales and make other competitor's marketing efforts fail. This situation will put businesses ahead of their competitors.

\section{References}

Aaker, D. A. (1991). Managing Brand Equity: Capitalizing on the Value of a Brand Name. The Free Press, Macmillan Inc., New York, USA.

Aaker, D. A. (1996). Measuring Brand Equity: A Cross Products and Markets. California Management Review. Vol. 38. No. 3, 102-120.

Aaker, D. A. (2009). Marka Değeri Yönetimi. E. Orfanlı (Çev). İstanbul: MediaCat Yayınları.

Altunışık, R., Coşkun, R., Bayraktaroğlu, S. and Yıldırım, E. (2012). Sosyal Bilimlerde Araştırma Yöntemleri. (7.Baskı). Adapazarı: Sakarya Yayıncılık.

Ayas. N. (2012). "Marka Değeri Algılamalarının Tüketici Satın Alma Davranışı Üzerine Etkisi”, Girişimcilik ve Kalkınma Dergisi, 7 (1), 163-183.

Baron, R. M, and Kenny, D. A. (1986). “The Moderator - Mediator Variable Distinction in Social Psychology Research: Conceptual, Strategic and Statistical Considerations", Journal of Personallity and Social Psychology, Vol. 51, No. 6, $1173-1182$.

Chang, H. H. and Liu, Y. M. (2009). “The Impact of Brand Equity on Brand Preference and Purchase Intentions in the Service Industries", The Service Industries Journal, Vol. 29, No. 12, 1687-1706.

Chen, C.F. and Chang, Y.Y. (2008). "Airline Brand Equity, Brand Preference and Purchase Intentions - The Moderating Effects of Switching Costs", Journal of Air Transport Management, 14, 40-42.

Chiaravalle, B. and Schenck, B. F. (2013). Markalaşma Meraklısına. İstanbul: Doğan Egmont Yayıncilık.

Clifton, R. (2014). Markalar ve Markalaşma. M. Ç. Şenerdi (Çev). İstanbul: İş Bankası Kültür Yayınları.

Cobb-Walgren, C.J., Ruble, C.A. and Donthu, N. (1995). "Brand Equity, Brand Preference and Purchase Intention”, Journal of Advertising, 24 (3), 25-40. 
Çiftci, S. and Koçak, A. (2009). "Aktif-Pasif Kulaktan Kulağa İletişim ve Aktif Kulaktan Kulağa İletişimi Etkileyen Faktörler Üzerine Bir Çalışma”, Ankara Üniversitesi Siyasal Bilgiler Fakültesi Dergisi, 4 (64), 101-116.

Erdil, T. S. and Uzun, Y. (2010). Marka Olmak. (2. Baskı). İstanbul: Beta Yayınları.

Farquar, P. H. (1989). "Managing Brand Equity", Journal of Marketing Research, Septemper, 24-33.

Fornell, C. and Larcker, D.F. (1981). "Evaluating Structural Equation Models with Unobservable Variables and Measurement Error", Journal of Marketing Research, $48,39-50$.

Godes, D. and Mayzlin, D. (2004). "Using Online Conversation to Study Word of Mouth Communication”, Marketing Science, Vol. 23, No. 4, 545-560.

Goyette, I., Ricard, L., Bergeron, J. and Marticotte, F. (2010). "e-Wom Scale: Word of Mouth Measurement Scale for e-Services Context", Canadian Journal of Administrative Sciences, 27, 5-23.

Hatch, M. and Schultz, M. (2012). Marka Girişimi. U. Mehter (Çev). İstanbul: Brandage Yayınları.

Interband (2013). Access Date: 07 November 2013, http://interbrand.com/en/bestglobal-brands/2013/Best-Global-Brands-2013.aspx.

Kaputa, C. (2012). Sen Bir Markasın. (2. Baskı). E. Yıldırım (Çev). İstanbul: MediaCat Yayınları.

Karaca, Y. (2010). Tüketici Satın Alma Karar Sürecinde Ağızdan Ağıza Pazarlama. İstanbul: Beta Yayınları.

Kavas, A. (2004). "Marka Değeri Yaratma", Pazarlama İletişim ve Kültürü Dergisi, Cilt: 3, Sayı: 8, 16-25.

Keller, K. L. (1993). "Conceptualizing, Measuring and Managing Customer-Based Brand Equity”, Journal of Marketing, Vol. 57, No. 1, 1-22.

Keller, K. L. (1998). Strategic Brand Management: Building, Measuring and Managing Brand Equity. Upper Saddle River. New Jersey: Prentice-Hall.

Keller, K. L. (2003). Strategic Brand Management: Building, Measuring and Managing Brand Equity. (Second Edition). New Jersey: Prentice-Hall.

Keskin, H. D. and Yıldız, S. (2010). "Tüketicilerin Marka Tercihlerinde Etkili Olan Faktörler ile Marka İmajı'nın Marka Değeri Üzerindeki Etkileri: Trabzon Örneği”, Dumlupınar Üniversitesi Sosyal Bilimler Dergisi, Sayı: 27, 239-254.

Kocaman, S. and Güngör, İ. (2012). "Destinasyonlarda Müşteri Temelli Marka Değerinin Ölçülmesi ve Marka Değeri Boyutlarının Genel Marka Değeri Üzerindeki Etkileri", International Journal of Alanya Faculty of Business, 4 (3), 143-161.

Kotler, P. (1999). Marketing Management Analysis, Planning, Implementation and Control. (Nineth Edition). New Jersey: Prentice Hall, International Inc.

Kotler, P. (2011). On Ölümcül Pazarlama Günahı. (4. Baskı). B.A dıyaman (Çev). İstanbul: MediaCat Yayınları. 
Kotler. P. (2012). Soru ve Cevaplarla Günümüzde Pazarlamanın Temelleri. (3. Bask1). Ü. Şensoy (Çev). İstanbul: Optimist Yayınları.

Kotler, P., Armstrong, G., Saunders, J. and Wong, V. (1996). Principles of Marketing. The European Edition, Europe: Prentice Hall.

Lassar, W., Mittal, B. and Sharma, A. (1995). "Measuring Consumer-Based Brand Equity", Journal of Consumer Marketing, Vol. 12, No. 4, 4-11.

Meydan, C. H. and Şeşen, H. (2011). Yapısal Eşitlik Modellemesi AMOS Uygulamaları. Ankara: Detay Yayıncılı.

Meyers, C.A. (2003). "Managing Brand Equity: A Look at the Impact of Attributes", Journal of Product and Management, 12 (1), 39-51.

Moradi, H. and Zarei, A. (2011). "The Impact of Brand Equity on Purchase Intention and Brand Preference - The Moderating Effects of Country of Origin Image", Australian Journal of Basic and Applied Sciences, 5 (3), 539-545.

Netemeyer, G. R., Krishan, B. Pulling, C., Wang, G., Yağc1, M., Dean, D., Ricks, J. and Wirth, F. (2004). "Developing and Validating Measures of Facets of CustomerBased Brand Equity", Journal of Business Research, Vol. 57, 209-224.

Odabaşı, Y. and Oyman, M. (2007). Pazarlama İletişim Yönetimi. (7. Baskı). İstanbul: MediaCat Yayınları.

Pappu, R., Quester, P. G. and Cooksey, R. W. (2005). "Consumer-Based Brand Equity: Improving the Measurement-Emprical Evidence", Journal of Product and Brand Management, Vol. 14, No. 2/3, 143-154.

Pappu, R., Quester, P. G. and Cooksey, R. W. (2006). "Consumer-Based Brand Equity and Country of Origin Relationships", European Journal of Marketing, Vol. 40, No. 55/6, 696-717.

Park, C. S. and Srinivasan, V. (1994). "A Survey Based Method for Measuring and Understanding Brand Equity and It's Extendability", Journal of Marketing Research, Vol. 31, 271-288.

Ries, A. and Ries, L. (2005). Marka Yaratmanın 22 Kuralı. A. Özdemir (Çev). İstanbul: MediaCat Yayınları.

Samutachak, B. and Li, D. (2012). "The Effects of Centality and Prominence of Nodes in the Online Social Network on Word of Mouth Behaviors", Journal of Academy of Business and Economics, Vol. 12, No. 2, 125-148.

Sarışık, M. and Özbay, G. (2012). "Elektronik Ağızdan Ağıza İletişim ve Turizm Endüstrisindeki Uygulamalar İlişkin Bir Yazın İncelemesi”, Uluslararası Yönetim İktisat ve İşletme Dergisi, Cilt: 8, Sayı: 16.

Sernovitz, A. (2012). Fısıltının Gücü. İ. Çetin (Çev). İstanbul: Optimis Yayınları.

Taşkın, Ç. and Akat, Ö. (2010). "Tüketici Temelli Marka Değerinin Yapısal Eşitlik Modelleme ile Ölçümü ve Dayanıklı Tüketim Malları Sektöründe Bir Araştırma”, İşletme ve Ekonomi Araştırmaları Dergisi, 1 (2), 1-16.

Temporal, P. (2011). İleri Düzey Marka Yönetimi. A. Kuruoğlu vd. (Çev). İstanbul: Brandage Yayınları. 
Tolba, A.H. (2011). "The Impact of Distribution Intensity on Brand Preference and Brand Loyalty", International Journal of Marketing Studies, Vol.3, No.3, 56-66.

Tosun, N. B. (2014). Marka Yönetimi. (2. Bask1). İstanbul: Beta Yayınları.

Ural, T. and Perk, H.G. (2012). “Tüketici Temelli Marka Değerinin Kişisel Bilgisayar Satın Alma Niyeti Üzerine Etkisi: Antakya'da Bir Çalışma”, Anadolu Üniversitesi Sosyal Bilimler Dergisi, 12 (3), 11-26.

Yazgan, H.İ., Kethüda, Ö. and Çatı, K. (2014). "Tüketici Temelli Marka Değerinin Ağızdan Ağıza Pazarlamaya Etkisi”, C.Ü.İktisadi ve İdari Bilimler Dergisi, Cilt:15, Sayı:1, 237-252.

Yoo, B., Donthu, N. and Lee, S. (2000). "An Examination of Selected Marketing Mix Elements and Brand Equity", Journal of the Academy of Marketing Science, Vol. 28, No. 2, 195-211.

http://www.tuik.gov.tr/UstMenu.do?metod=temelist, Access Date: 01 March 2014. 